\title{
Assistência e Atenção
}

\section{Health care and "Atenção"}

A deturpação dos limites dentro dos quais os sentidos dos termos "assistência" e "atenção" têm validade, no campo da Saúde Pública, pode, infortunadamente, originar consideráveis mal entendidos.

Não há como negar que quanto mais amplo for o conhecimento de uma língua, o que se consegue muito mais pela Glotologia, do que pelo simples exercício prático, tanto mais eficiente será o 1 rocesso de comunicação. Afinal a "linguagem é, por assim dizer, a forma e concretização do pensamento" permitindo que exprimamos "aos outros com maior precisão o que se passa dentró de nós".

O uso de uma língua de forma correta e pura é, por outro lado, o mais sólido obstáculo à invasão dos estrangeirismos que todos os dias nos assaltam, por vezes, com resultados que atingem as raias do cớmico.

A propósito da linguagem são mujto mais uteis as explicaçōes filológicas do que 0 ato de recorrer-se a argumentações tendentes a conferir à terminologia utilizada certos sentidos ideológicos com o que se descaracterizam significados e se criam modismos. Considerar que o termo "assistência", quando usado no campo da Saúde Pública, traz implícita a idéia de que existe "quem assiste" e "quem é assistido", idéia esta não compatível com o que hoje se considera serem as verdadeiras ações da Saúde Pública, cujos usuários não devem ser considerados (ou considerarem-se eles próprios) receptores carregados de extrema passividade, é, em nosso entender e como já dissemos, descaracterizar o verdadeiro significado do termo. Particularmente quando se propõe sua substituição pelo termo "atenção", este sim, livre daquele tão pejorativo significado, e mais apto a abraçar multiplicidade de açōes da Saúde, não deixando para os usuários qualquer possibilidade de que venham a considerar-se mais uma vítima, excluída injustamente da ação em pauta. Naturalmente, neste caso existe, também, o agente "que atende" e o "que é atendido", situação que, realmente, é indistinguível daquela em que "se assiste" e "se é assistido". Mas parece ser necessário estabelecer a diferença de significado e partir para uma situação de desuso do termo a que quer atribuir-se significado prejudicial às boas ações da Saúde.

Ainda que hoje ninguém se atreva a exigir pureza ortodoxa na linguagem, coisa já de si essencialmente evolutiva, persiste-se no hábito de salientar, para edificação de todos, a genuidade do novo termo proposto, e a sua validade para que as ações da Saúde Pública frutifíquem. É óbvio que o processo exige a disponibilidade de autoridades filológicas que saibam aconselhar... Mas estas não faltam e são os próprios frutos do processo. Exige ainda que saliente, constantemente, a atualidade e perfeita adequação da nova terminologia, não distraida por argumentos estranhos, ainda que justificáveis. E assim entra no uso corrente das ações de Saúde a palavra "atenção" (realmente um estrangeirismo) em substituição a "assistência" (genuinamente português). Sabe-se com uma boa dose de segurança, que é muitas vezes útil conferir a determinados termos novo significado, desejando-se que, no caso da Saúde Pública, os resultados sociais das ações que the são peculiares, melhor frutifiquem. Isso é perfeitamente respeitável e não pressupõe qualquer tipo de improvisação optimista. Acontece que no presente exemplo o significado de "atenção" não refere, em nenhuma situação, ações que vão ao encontro de necessidades de saúde de qualquer grupo social. O que já acontece com o significado de "assistência".

Também é verdade ser inútil entrar no âmbito desta argumentação, pois não se argumenta contra estados de espírito. Mas a intensidade do processo pode conter em si a própria impossibilidade de manter o uso por longo tempo, quando surge, por exemplo, uma situação nova, capaz de exigir novos conceitos, para novas ações. 
"Assistência" é termo correto, mas poderia até lançar-se mão do termo "cuidado", usado na versão, em português, do Relatório da Conferência Internacional de Alma-Ata e deixar, definitivamente, "atencion" para a língua espanhola.

Mas, os assuntos não se esgotam, o que se esgota são os homens que pensam sobre os assuntos.

José Alberto Neves Candeias Editor Associado 